Pakistan Journal of Social Sciences 8 (2): 94-99, 2011

ISSN: $1683-8831$

(C) Medwell Journals, 2011

\title{
A Post-Training Job Performance of Sandwich and Full-Time Nigeria Certificate in Education Graduates in Ogun State, Nigeria
}

\author{
${ }^{1}$ Akinwumi Femi Sunday and ${ }^{2}$ Adeyanju Hammed Idowu \\ ${ }^{1}$ Department of Educational Management, University of Ibadan, Ibadan, Nigeria \\ ${ }^{2}$ Tai Solarin University of Education, Ijagun, Ijebu-ode, Ogun State, Nigeria
}

\begin{abstract}
It is generally perceived that teachers' attitude to work is one of the major causes of primary school pupils' poor performance in examination. While some people shift the blame on sandwich Nigerian Certificate in Education (NCE) teachers. Others maintain that the full-time NCE teachers are accountable. This study therefore, compares the post-training job-performance of sandwich and full-time NCE graduates in Ogun state, Nigeria with a view to determining the level of efficiency of the products of the programme. The study adopted the descriptive survey design. A multi-stage technique was used to select 1,750 teachers from 300 public primary schools in Ogun state while 100 employers of labour and 50 stakeholders in education in the state. Two self-develop and validated instruments: graduate teachers' performance assessment questionnaire $(r=0.81)$ and graduate personnel appraisal questionnaire $(\mathrm{r}=0.86)$ were used to collect data. About 5 null hypotheses were generated and tested at 0.05 level of significance. Data were analyzed using t-test and multiple regressions. Result showed that there were no significant differences in sandwich and full-time NCE graduates jobperformance variables: lesson preparation $(\mathrm{t}=1.67 ; \mathrm{p}>0.05)$ and teaching methods $(\mathrm{t}=1.03 ; \mathrm{p}>0.05)$ and knowledge of professional practice and ethics $(t=1.99 ; \mathrm{p}>0.05)$. Furthermore, lesson preparation, teaching methods and knowledge of professional practice and ethics correlate positively with the productivity of sandwich and full-time graduates, $(R=0.656)$ and full-time graduates $(R=0.800)$. They also accounted for $42.6 \%$ (adj. $R^{2}=0.426$ ) of the total variance in sandwich graduates productivity while for full-time graduates, this was graduates this was found to be $63.5 \%$ (adj. $\mathrm{R}^{2}=0.635$ ). The result further showed that for sandwich graduates, the dependent variables made the following contributions to the prediction of job performance: lesson preparation $(B=0.258 ; p<0.05)$, teaching methods $(B=127 ; p<0.05)$ and knowledge of professional practice and ethics $(B=0.016 ; \mathrm{p}<0.05)$. In order to enhance the quality of sandwich education there is need for upward adjustment of sandwich programmes' contact period, introduction of entrance examination as well as creation of enabling environment for teaching and learning.
\end{abstract}

$\underline{\text { Key words: Job-performance, post-training, enabling environment, efficiency, sandwich, education, Nigeria }}$

\section{INTRODUCTION}

Background to the study: Education is a priceless asset of fundamental value to the individual and the society. It provides a sound basis for individuals to develop their potentialities. It is a powerful instrument for effecting national development. It is a dynamic instrument of change. The wealth of nation is determined to a large extent by the quality as well as the quantity of its human resources that ultimately set the pace for the social, economic or political development of a nation. It is for this reason that Governments all over the world pursue vigorously the task of building up their human capital Owolabi (1987). It is thus evident that education is one of the greatest tools for the advancement of any nation and so no country can afford to neglect the education of her citizens. Incidentally, education is a very expensive venture and numerous factors help to determine the extent to which objectives for a sound and productive educational programme can be established and maintained at any given point in time. The operational factors are psychological, economic, social, political and cultural in nature. They contribute in varying degree to the quality of education provided in a society, state or country. For some time now, the question of rise or fall in the standard of education has formed the subject of discussion among scholars and the general public in Nigeria.

There is no consensus among the generality of the people as to whether or not the standard of education in the country is rising, failing or has risen or fallen. The debate has continued unabated. It is however, evident that performance of the pupils and students in internal

Corresponding Author: Akinwumi Femi Sunday, Department of Educational Management, University of Ibadan, Ibadan, Nigeria 
examination at all levels of education have declined drastically. It is also evident that there is erosion of quality because the curriculum is quite different from the olden days and that cases of examination malpractice have assumed alarming proportions in the school system. There is a decline in the employment opportunity as well as moral and social life of the youths.

The background to this study rests on the report of the Ashby Commission in 1958 which recommended that higher education must be built upon the foundation laid by the primary and secondary schools. The report stressed that if the foundations are too small or too narrow the structure of higher education cannot be large or varied enough to meet the needs of the society. If the foundations are made of materials that will crumble in few years the whole structure will be in danger. In the same vein, it is stated in paragraph 13 of the National Policy on Education that since the totality of education system rests upon the primary education system, the primary level is the key to the success or failure of the whole system (Federal Republic of Nigeria. National Policy of Education-Revised Edition in 1981). It is generally believed that teachers' attitude to work is one of the causes of primary school pupils poor performance Bamisaye (2000) and Ogunniyi (1996) backed this up. This has been linked to the quality of training of teachers which is either full-time or sandwich. It is important to note that if the primary level of education is to be functional, productive and students' performance improve, greater attention must be focused on the ways NCE teachers perform their instructional duties.

Aminu aptly observes that teachers are indispensable within the teaching-learning process also trained and effective teachers are the principal assets of any educational system. Teachers constitute not only a vital input to education but also they are the major factor in the production process and in the determination of the output system.

Statement of the problem: The question of rise or fall in the standard of education has formed the subject of discussion among scholars and the general public in Nigeria. There is no consensus among the generality of the people as to whether or not the standard of education in the country is failing, rising or has risen or fallen.

The controversy over the quality of the two modes of NCE programme viz sandwich and full-time has been generating a lot of repulse among the beneficiaries (students) of these two programmes, their lecturers and even the employers of labthe. While few people believe in the quality of sandwich programme, other believe are that the quality is substandard inferior when compared with full-time. This study therefore compares the post-training job-performance of sandwich and full-time NCE graduates in Ogun state, Nigeria.

\section{Research hypotheses}

Ho 1: There is no significant different in the lesson note preparation of the sandwich NCE graduate teachers and full-time NCE graduate teachers as sub-variable for measuring job-performance.

Ho 2: There is no significant different in the teaching methods of sandwich NCE graduate teachers and full-time NCE graduate teachers as sub-variable for measuring job-performance.

Ho 3: There is no significant different in the knowledge of professional practice and ethics of sandwich NCE graduate teachers and full-time NCE graduate teachers as sub-variable for measuring job-performance.

Ho 4: There is no significant composite effect of the variables (lesson note preparation, teaching methods and knowledge of professional practice and ethnics) on job-performance, sandwich NCE graduate teachers and full-time NCE graduate teachers.

Ho 5: There are no significant relative effects of the variables (lesson note preparation, teaching methods and knowledge of professional practice and ethics) on job-performance, sandwich NCE graduate teachers and full-time NCE graduate teachers.

Studies on lesson preparation (sandwich and full-time): This is a plan of what the teacher wants to do during the specified period. It is either daily or weekly plan. The success of any course or lesson depends to a large extent upon the teachers planning and the skillfulness with which the activity is accomplished. An important thing the teacher must take note of is that he is not planning for himself rather, he is planning for the students. He should therefore, put the children in mind in his planning. The subject teacher must be familiar with some important school documents in the course of planning his work. Prominent among such documents are the syllabus and the scheme of work.

Studies on teaching methods (sandwich and full-time): In a bid to bring learning a teacher engages in certain activities. He may talk, demonstrate, give instructions, read, get his students to act a play etc., all these are his strategies for effecting learning. They are his teaching 
methods. Teaching methods are those strategies which the teacher uses to effect learning. Learning experience is that experience which the teacher puts the learners through as a result of what he (the teacher) does Ajiboye et al. (2005).

Studies on professional practice and ethics sandwich and full-time): Akinpelu (1997) postulates that the procedures adopted in imparting learning must be morally and pedagogically sound. The person to whom the teaching is directed must have the cognitive competence. For example for teacher to practice what he preaches when discussing discipline his action according to Taiwo.

Teachers exert a great deal of influence on students, the children look up to him for guidance, support and protection. Children learn from him informally by observing his attitudes, manner, conduct and general behavior and formally through his teachers in the classrooms

Effect of mode of training on job attitude and performance: Many studies conducted over the years have established the existence of variables and their concomitant relationship with NCE graduate teachers job performance and students academic achievement (Adeniji, 1999; Ajayi, 1981). They relate the teachers' level of job performance to some selected demographic and institutional variables like age, educational qualification, sex, teaching experience and teachers' attitude to teaching.

\section{MATERIALS AND METHODS}

Research design: The descriptive survey research design was adopted to determine and compare post-training job-performance of sandwich and full-time NCE graduate teachers is Ogun state within the last 10 years. The research was essentially an ex-post-facto design as no attempt was made to manipulate any of the variables because the variables existed before the research was carried out.

Sample size/sampling techniques: The population consists of 10,992 NCE graduate teachers (1996-2005) out of which 1,800 were selected and 1,750 responded to the instruments addressed to them. The multistage sampling techniques was adopted for the study i.e., cluster; stratified and random sampling technique. Cluster or area sampling was used to divide the population into units with distinct boundaries (local government (20) while stratified random sampling was used to select the schools with $40 \%$ of both NCE full-time and sandwich graduate teachers within the last 10 years (1996-2005) as variables of interest from which elements were randomly drawn. The three sampling techniques were used to select 1,750 respondents.

A self-developed and validated instrument: Graduate Performance Assessment Questionnaire (GTPAQ) was used to collect data. Head teachers, assistants and head of departments from sampled schools responded to the questionnaire on the NCE graduate teachers under them. T-test and regression analysis were used to analyze data on NCE graduate job-performance.

\section{RESULTS}

Hypothesis 1: There is no significant different in the lesson not preparation as sub-variable for measuring sandwich NCE graduate teachers and full-time NCE graduate teachers' job performance. From Table 1, the quality of lesson note preparation by full-time NCE graduate teachers is higher $(\mathrm{x}=23.42, \mathrm{SD}=3.16)$ than that of their counterparts who are sandwich NCE graduates teachers $(\mathrm{x}=20.68, \mathrm{SD}=2.53)$.

This shows that full-time NCE graduate teachers are better in lesson note preparation than their sandwich counterparts going by their mean scores. This difference is however not significant $(\mathrm{t}=1.670, \mathrm{df}=1748 ; \mathrm{p}>0.05)$. On the basis of this finding, hypothesis I was accepted.

Hypothesis 2: There is no significant difference in the teaching methods as sub-available for measuring sandwich NCE graduate teachers and full-time NCE graduate teachers. From Table 2, the sandwich NCE graduate teachers obtained a mean score of ( $x=30.97$, $\mathrm{SD}=3.36$ ) in teaching methods used while the full-time NCE graduate teachers obtained a mean score of

Table 1: The t-test comparison of lesson note preparation as sub-variable for measuring sandwich and full-time NCE graduate teachers jobperformance

\begin{tabular}{lccccccc}
\hline NCE graduates & $\mathrm{N}$ & $\mathrm{x}$ & $\mathrm{SD}$ & $\mathrm{t}$-value & df & Sig. (p) & Remarks \\
\hline Sandwich & 869 & 20.68 & 2.53 & 1.670 & 1748 & 0.097 & NS \\
Full-time & 881 & 23.42 & 3.16 & - & - & - & - \\
\hline \multicolumn{2}{l}{ NS = Not Significant at $\mathrm{p}>0.05$} & & & &
\end{tabular}

NS $=$ Not Signific ant at $\mathrm{p}>0.05$

Table 2: t-test comparison of teaching methods as sub-variable for measuring sandwich and full-time NCE graduate teachers jobperformance

\begin{tabular}{lccccccc}
\hline NCE graduates & $\mathrm{N}$ & $\overline{\mathrm{x}}$ & $\mathrm{SD}$ & $\mathrm{t}$-value & df & Sig. (p) & Remarks \\
\hline Sandwich & 869 & 30.97 & 3.36 & 1.030 & 1748 & 0.307 & NS \\
Full-time & 881 & 32.33 & 4.06 & - & - & - & - \\
\hline
\end{tabular}

$\mathrm{NS}=$ Not Signific ant at $\mathrm{p}>0.05$ 
Table 3: The t-test comparison of knowledge of professional practice and ethics as sub-variable for measuring sandwich and full-time nce graduate teachers job-performance

\begin{tabular}{|c|c|c|c|c|c|c|c|}
\hline NCE graduates & $\mathrm{N}$ & $\bar{x}$ & SD & $t$-value & $\mathrm{df}$ & Sig. (p) & Remarks \\
\hline Sandwich & 869 & 42.63 & 5.01 & 1.990 & 1748 & 0.055 & NS \\
\hline Full-time & 881 & 46.54 & 3.18 & - & - & - & - \\
\hline \multicolumn{8}{|c|}{$\mathrm{NS}=$ Not Signific ant at $\mathrm{p}>0.05$} \\
\hline \multicolumn{8}{|c|}{$\begin{array}{l}\text { Table 4: Summary of regression analysis of independent variables on } \\
\text { sandwich NCE graduate teachers job-performance }\end{array}$} \\
\hline $\mathrm{R}$ & $\mathrm{R}^{2}$ & & & usted $\mathrm{R}^{2}$ & & SE of th & estimate \\
\hline 0.656 & 0.43 & & & 0.426 & & & \\
\hline
\end{tabular}

$(\mathrm{x}=32.33, \mathrm{SD}=4.06)$. This shows that full-time NCE graduate teachers are better in teaching methods than their sandwich counterparts going by their mean scores. This difference is however, not significant $(\mathrm{t}=1.030$, $\mathrm{df}=1748 ; \mathrm{p}>0.05)$. On the basis of this finding hypothesis 2 was accepted.

Hypothesis 3: There is no significant difference in the knowledge of professional practice and ethics as sub-variable for measuring sandwich NCE graduate teachers and full-time NCE graduate teachers jobperformance. Table 3 showed that the sandwich NCE graduate teachers obtained a higher mean score of ( $\mathrm{X}=42.63 ; \mathrm{SD}=5.01)$ in knowledge of professional practice and ethics when compare with their full-time NCE graduate teachers $(\mathrm{X}=46.54 ; \mathrm{SD}=3.18)$ in their knowledge of professional practice and ethics. This difference is found to be in significant $(\mathrm{t}=1.99$; $\mathrm{df}=1748$; $\mathrm{p}>0.05$ ). Therefore, hypothesis 3 was accepted.

Hypothesis 4a: There is no significant composite effect of the variables (lesson note preparation, teaching methods and knowledge of professional practice and ethics) on job-performance of sandwich NCE graduate teachers and full-time NCE graduate teachers. Table 4 showed that the 3 independent variables correlated positively with sandwich NCE graduate teachers' job-performance $(\mathrm{R}=0.656)$. This implied that 3 variables viz: lesson note preparation, teaching methods and knowledge of professional practice and ethics were quite important and relevant towards the determination of job-performance of the sandwich NCE graduate teachers.

Also, the table showed that $42.6 \%$ of the total variance in the job-performance of the NCE sandwich graduate teachers was accounted for by the 3 factors. This implied that the remaining $57.4 \%$ was due to other factors not included in this study. Table 4 showed that the adjusted $\mathrm{R}^{2}$ values is 0.426 while Table 5 showed the significant values of $(f=16.516 ; p<0.05)$. This means that the adjusted $\mathrm{R}^{2}$ value was not due to chance. Hypothesis 4a was not accepted.
Table 5: ANOVA table for regression of sandwich NCE graduate teachers job-performance

\begin{tabular}{|c|c|c|c|c|c|}
\hline $\begin{array}{l}\text { Sum of } \\
\text { variance }\end{array}$ & $\begin{array}{l}\text { Sum of } \\
\text { square }\end{array}$ & $\mathrm{df}$ & Mean square & $\mathrm{F}$ & Sig. \\
\hline Regression & 4558.860 & 3 & 1519.620 & 16.516 & $0.000^{*}$ \\
\hline Residual & 52842.323 & 866 & 92.010 & - & - \\
\hline Total & 62801.184 & 869 & - & - & - \\
\hline
\end{tabular}

*Significant at $\mathrm{p}<0.05$

Table 6: Summary of regression analysis of independent variables of fulltime NCE graduate teachers job-performance

\begin{tabular}{lccc}
\hline $\mathrm{R}$ & $\mathrm{R}^{2}$ & Adjusted $\mathrm{R}^{2}$ & $\mathrm{SE}$ of the estimate \\
\hline 0.800 & 0.640 & 0.639 & 5.1808 \\
\hline
\end{tabular}

Table 7: ANOVA table for regression of full-time NCE graduate teachers job-performance

Sum of variance Sum of square df Mean square F $\quad$ Sig.

\begin{tabular}{llllll}
\hline Regression & 30239.946 & 3 & 10079.982 & 375.548 & 0.000
\end{tabular}

$\begin{array}{lllclll}\text { Residual } & 16990.201 & 878 & 26.841 & - & - \\ \text { Total } & 47230.147 & 881 & - & - & -\end{array}$

Significant at $\mathrm{p}<0.05$

Hypothesis 4b: There was no significant composite effect of the variables (lesson note preparation, teaching methods and knowledge of professional practice and ethics) on job-performance of full-time NCE graduate teachers. From Table 6 , the 3 independent variables correlated positively with the full-time NCE graduate teachers job-performance $(\mathrm{R}=0.800)$. This implied that the 3 factors viz: lesson note preparation, teaching methods and knowledge of professional practice and ethics were relevant towards the determination of full-time NCE graduate teachers' job-performance.

Also, the adjusted $\mathrm{R}^{2}$ values of 0.639 obtained showed that $63.9 \%$ of the total variance in the full-time NCE graduate teachers job-performance was accounted for by the 3 factors. The remaining $36.1 \%$ was ascribed to other factors not investigated in this study. In order to test the significant of the adjusted $R^{2}$ value, the table was showed below. Table 6 showed the adjusted $\mathrm{R}^{2}$ value obtained i.e., 0.639 while Table 7 showed the significant level of $(\mathrm{F}=375.548, \mathrm{p}<0.05)$. Hence hypothesis $6 \mathrm{~b}$ was not accepted.

Hypothesis 5: There was no significant relative effect of the variables (lesson note preparation, teaching methods and knowledge of professional practice and ethics) on the job-performance of, sandwich NCE graduate teachers and full-time NCE graduate teachers.

Table 8 showed that lesson note preparation made the greatest contribution to sandwich NCE graduate teachers job-performance $(\mathrm{B}=0.258 ; \mathrm{p}<0.5)$. This contribution was significant. It was followed by teaching methods $(B=0.127 ; \mathrm{p}<05)$ which was also significant while knowledge of professional practice and ethics made the least contribution which was not significant 
Table 8: Relative contribution of the independent variables on sandwich NCE graduate teachers job-performance

\begin{tabular}{|c|c|c|c|c|c|c|}
\hline \multirow[b]{2}{*}{ Characteristics } & \multicolumn{2}{|c|}{$\begin{array}{l}\text { Unstandardised } \\
\text { coefficient }\end{array}$} & \multirow{2}{*}{$\begin{array}{l}\text { Stand- } \\
\text { ardised } \\
\text { coefficient } \\
\text { Beta }\end{array}$} & \multirow[b]{2}{*}{ Rank } & \multirow[b]{2}{*}{$\mathrm{T}$} & \multirow[b]{2}{*}{ Sig. } \\
\hline & B-Beta & $\mathrm{SE}$ & & & & \\
\hline Constant & 51.419 & 6.306 & - & - & 8.154 & 0.000 \\
\hline Lesson preparation & -0.382 & 0.057 & 0.258 & $1 \mathrm{st}$ & -6.652 & $0.000^{*}$ \\
\hline Teaching methods & 0.193 & 0.059 & 0.127 & 2nd & 3.263 & $0.001^{*}$ \\
\hline $\begin{array}{l}\text { Knowledge of } \\
\text { professional practice }\end{array}$ & $\begin{array}{l}-2.29 \mathrm{E}-02 \\
\text { and ethics }\end{array}$ & 0.053 & 0.016 & $3 r d$ & -0.430 & 0.668 \\
\hline
\end{tabular}

Table 9: Relative contribution of the independent variables of NCE full-time graduate teachers job-performance

\begin{tabular}{llllllll}
\hline & \multicolumn{2}{l}{$\begin{array}{l}\text { Unstandardised } \\
\text { coefficient }\end{array}$} & \multicolumn{2}{l}{$\begin{array}{l}\text { Stand- } \\
\text { ardised }\end{array}$} & & & \\
& ------------- & coefficient & & & \\
Characteristics & B-Beta & SE & Beta & Rank & T & Sig. \\
\hline CConstant & 1.072 & 3.406 & - & - & 0.315 & 0.753 \\
Lesson preparation & -0.196 & 0.031 & 0.153 & 2nd & -6.340 & $0.000^{*}$ \\
Teaching methods & 1.071 & 0.320 & 0.809 & 1 st & 33.499 & $0.000^{*}$ \\
Knowledge of & $-1.18 \mathrm{E}-02$ & 0.290 & 0.010 & 3rd & -0.410 & 0.682 \\
professional practice and ethics & & & & & \\
*Significant at $\mathrm{p}<0.05$ & & & & & &
\end{tabular}

$(\mathrm{B}=0.016 ; \mathrm{p}>0.05)$. The magnitude of the relative contributions were represented as lesson note preparation $>$ teaching methods $>$ knowledge of professional practice and ethics. Hence, the hypothesis 5 was rejected for lesson note preparation and teaching methods while it was rejected for knowledge of professional practice and ethics of NCE Sandwich graduate teachers. From Table 9, teaching methods made the greatest contribution to NCE full-time graduate teachers' job-performance ( $\mathrm{B}=0.809$; $\mathrm{p}<0.05$ ) followed by lesson note preparation $(\mathrm{B}=0.153 ; \mathrm{p}<0.05$ ) while knowledge of professional practice and ethics made the least contribution ( $\mathrm{B}=0.010 ; \mathrm{p}>0.05$ ). Of these, only the contribution of knowledge of professional practice and ethics was not significant. The order of decreasing magnitude of the contribution was teaching methods lesson note preparation> knowledge of professional practice and ethics. Hence, hypothesis 7 was rejected for teaching methods and lesson note preparation but not rejected fore knowledge of professional practice and ethics.

\section{DISCUSSION}

From Table 1 the higher in the quality of lesson note preparation as sub-variable for measuring full-time NCE graduate teachers job-performance $(\mathrm{x}=23.42, \mathrm{SD}=3.16)$ compared with their sandwich counterparts $(x=20.68$, $\mathrm{SD}=2.53$ ) showed that full-time NCE graduate teachers were better in lesson note preparation than their sandwich counterparts going by their mean scores. This difference was however, not significant $(t=1.670, \mathrm{df}=1748 ; \mathrm{p}>0.05)$.
On the basis of this finding, hypothesis 1 was accepted. This corroborated Nwagwu whose findings revealed that there were strong indications that students learning does not receive adequate focus in the sandwich or in-service training programme like that of full-time programme. From Table 2, the sandwich NCE graduate teachers obtained a mean score of 30.97 in teaching methods used while the full-time NCE graduate teachers obtained a mean score of 32.33 .

This showed that full-time NCE graduate teachers were better in lesson note preparation than their sandwich counterparts going by their mean scores. This difference was however, not significant $(\mathrm{t}=1.670, \mathrm{df}=1748 ; \mathrm{p}>0.05)$. On the basis of this finding, hypothesis 1 was accepted. This supported Emenogu that it is wrong to assume that the mere fact of long teaching experience makes an individual capable teacher. Table 3 showed that the full-time NCE graduate teachers obtained a higher mean score $(\mathrm{X}=46.54 ; \mathrm{SD}=3.18)$ in their knowledge of professional practice and ethics when compared to the mean score of their sandwich counterparts ( $\mathrm{X}=42.63$; $\mathrm{SD}=5.01)$. This difference is found to be insignificant $(\mathrm{t}=1.99 ; \mathrm{df}=1748 ; \mathrm{p}>0.05)$. Therefore, hypothesis 3 was accepted.

The findings also supported Chiaha's findings that most of the part-time NCE graduate were not more reliable and obedient and were also difficult to control after the programme. Also, Obemeata (1995) was very concerned with what he described as the type of training given to teachers which was further debased by the production of half-baked teachers through sandwich or part-time programmes conducted by colleges of education and universities in the country.

Table 4 showed that the 3 independent variables correlated positively with sandwich NCE graduate teachers' productivity ( $\mathrm{R}=0.656)$. This implied that 3 variables viz: lesson note preparation, teaching methods and knowledge of professional practice and ethics were quite important and relevant towards the determination of job performance of the sandwich NCE graduate teachers. Also, the table showed that $42.6 \%$ of the total variance in the job-performance of the NCE sandwich graduate teachers was accounted for by the 3 factors. This implied that the remaining $57.4 \%$ was due to other factors not included in this study.

This was supported by Ochuche who opined that it was not easy to assess teaching effectiveness but felt that effectiveness to teachers at all levels of the educational system must be periodically determined and that in particular in the secondary schools and primary schools there was the need to obtain inputs from the teachers, his immediate supervisor, his colleagues, his 
students and ministry of Education/school Boards inspectors. Table 5 showed that the adjusted $R^{2}$ value of 0.426 was significant $(\mathrm{f}=16.516 ; \mathrm{p}<0.05$ ). This means that the adjusted $\mathrm{R}^{2}$ value was not due to chance. From Table 6 , the 3 independent variables correlated positively with the full-time NCE graduate teachers job-performance $(\mathrm{R}=0.800$ ). This implied that the 3 factors viz: lesson note preparation, teaching methods and knowledge of professional practice and ethics were relevant towards the determination of full-time NCE graduate teachers job-performance. Also, the adjusted $\mathrm{R}^{2}$ value of 0.639 obtained showed that $63.9 \%$ of the total variance in the full-time NCE graduate teachers job-performance was accounted for by the 3 factors. The remaining $36.1 \%$ was ascribed to other factors not investigated in this study.

This corroborates Fabayo, Farombi, Onwarakpa and Ogunniyi (1996) that low level of students' academic performance which is associated with the decline in the availability of teaching restheces in schools. Table 7 showed that adjusted $\mathrm{R}^{2}$ value obtained i.e., 0.639 was significant $(F=375.548, p<0.05)$. Hence hypothesis 4 b was rejected.

Table 8 showed that lesson note preparation made the greatest contribution to sandwich NCE graduate teachers' job-performance $(b=0.258 ; \mathrm{p}<0.5)$. This contribution was significant. It was followed by teaching methods $(\mathrm{B}=0.016 ; \mathrm{p}>0.05)$ which was also significant while knowledge of professional practice and ethics made the least contribution which was not significant ( $\mathrm{B}=0.015 ; \mathrm{p}>0.05)$.

The magnitude of the relative contribution were represented as lesson note preparation> teaching methods $>$ knowledge of professional practice and ethics. Hence, the hypothesis 5 was rejected for lesson note preparation, teaching methods while it was not rejected for knowledge of professional practice and ethics of NCE Sandwich graduate teachers. This supports Awomolo (1985) that teachers' performance is determined by the extent to which the teachers do enctheage classroom organisation and administration, teachers' interest in teaching job, his attendance in classroom, his method of evaluating students and the level of students' participation in school activities. From Table 9, teaching made the greatest contribution to NCE full-time graduate teachers' job-performance ( $\mathrm{B}=0.809 ; \mathrm{p}<0.05$ ) followed by lesson note preparation $(\mathrm{B}=0.153 ; \mathrm{p}<0.05$ ) while knowledge of professional practice and ethics made the least contribution $(\mathrm{B}=0.010 ; \mathrm{p}>0.05)$. Of these, only the contribution of knowledge of professional practice and ethics was not so significant. The order of decreasing magnitude of the contribution was teaching methods> lesson note preparation> knowledge of professional practice and ethics. Hence, the hypothesis was rejected for teaching methods and lesson note preparation but not rejected for knowledge of professional practice and ethics.

\section{CONCLUSION}

This study sought to establish the comparative study of post training job-performance of NCE sandwich and full-time graduates working in public primary schools in Ogun state. It traced the development of sandwich and full-time educational progrmme in Nigeria. It was concluded that full-time NCE graduate teachers performed better in sub-variables used in measuring job-performance like: lesson note preparation, teaching methods and knowledge of professional practice and ethics than their sandwich NCE graduate teachers that the little difference in post training job-performance of both NCE sandwich and full-time graduate teachers could only be corrected through effective monitoring of sandwich progrmmes; curbing of lecturers excessiveness, students exploitation and extending sandwich progrmme duration to make up for wider coverage.

\section{REFERENCES}

Adeniji, A.I., 1999. A path-analytic study of some teacher characteristics and teacher job performance in secondary schools in Ogun state, Nigeria. Ph.D. Thesis, University of Ibadan.

Ajayi, K., 1981. Job satisfaction among secondary school teachers in Nigeria. Afr. J. Educ. Res., 3: 28-34.

Ajiboye, S., Sola Adu and W. Amosun, 2005. Introduction to Social Studies: A Basic Text for Tertiary Institution Students. ERSG, Ibadan.

Akinpelu, J.A., 1997. Equity and Quality in University Continuing Education: Inaugural Lecture. University of Bostwana, Gbaborne, Botwswana.

Awomolo, A.A., 1985. Teachers effectiveness: Towards the definition of a complex concept, Ilorin. West Afr. J. Educ. Vocational Meas., 6: 1-9.

Bamisaye, E.A., 2000. New Sources of Funding the University System in Nigeria. Spectrum Book Ltd., Ibadan.

Obemeata, J.O., 1995. Education, an Unprofitable Industry in Nigeria. University of Ibadan, Ibadan, pp: 40.

Ogunniyi, M.B., 1996. Science, technology and mathematics: The problem of developing critical human capital in Africa. Int. J. Sci. Educ., 18: 267-284.

Owolabi, O., 1987. Politics and Cultural Content of Educational Planning. Aderibigbe Publishers, Ibadan. 